\title{
Large Llamas with Silver Shoes
}

\author{
V.G.A. Goss
}

Department of Engineering and Design, London South Bank University gossga@lsbu.ac.uk

\begin{abstract}
Drawing upon contemporary accounts, this paper analyzes conquistadors' and Incas' perceptions of each other's ungulates - that is, camelids and horses - from the first encounters in 1532 until 1536. The paper traces the evolution of those perceptions within the wider context of human-nonhuman animal relations, which differed between Spaniards and Andeans. Those differences are reflected in the respective languages. The paper finds a tension between a sense of familiarity and a sense of otherness. That tension manifested in a supernatural realm. The paper argues that nonhuman animal relations, particularly with respect to horses, played a central role in the invasion, but as the conflict unfolded the meanings of "human" and "animal," as understood by the protagonists, were perturbed. The paper presents a critique of Diamond's theory of nonhuman animal domestication.
\end{abstract}

\section{Keywords}

horses - camelids - llamas - conquistadors - Inca - Andeans - nonhuman animal camelid husbandry

\section{Introduction}

When the conquistadors invaded the Inca Empire in 1532, they stumbled upon widespread, sophisticated camelid husbandry, and the Andeans encountered horses for the first time. Drawing upon contemporary accounts, this paper examines the evolution of conquistadors' and Andeans' perceptions of each other's ungulates during those first encounters. It begins with a study of the first reports by conquistadors about camelid husbandry, followed in the next section with reports by Incas about horses. It then examines the incident when Atahualpa (1497-1533), the Inca Emperor, first encountered a horse.

(C) KONINKLIJKE BRILL NV, LEIDEN, 2017 | DOI 10.1163/15685306-12341443 
The next section analyzes the role of horses in the famous battle of Cajamarca, where just 162 conquistadors captured Atahualpa and killed thousands of his soldiers, without incurring a single casualty. The following section scrutinizes an incident at Pachacamá in which the Devil is featured. The penultimate section examines the centrality of horses in determining tactics in the battles that broke out a few years after Cajamarca. The conclusion includes a critique of Jared Diamond's theory of the advantageous role of Old World nonhuman animal domestication in the conquest of the New World. Though structured around some key events underpinning the conquistadors' invasion of the Inca Empire, this paper is about how Andeans and Europeans made sense of the new nonhuman animals they encountered. It concerns the tension between familiarity and a sense of otherness as two different traditions of human-nonhuman animal relations came into contact with each other.

\section{Flocks of Sheep}

On May 16, 1532, Francisco Pizarro (c. 1476-1541) together with 162 conquistadors and 62 horses reached the banks of River Chira, in the northern part of the Inca Empire (present-day Peru). Francisco Xeres (1495-1565), the Secretary to Francisco, recorded in his chronicle that the land contained "flocks of sheep" ("ganado de ovejas") (Xeres, 1534, p. 20). Those "sheep" were either llamas or alpacas. Xeres offered no description of them and certainly did not conceive of them as strange or exotic, as Anthony Pigafetta (1491-1534) had in 1520, following an encounter with a guanaco in Patagonia. ${ }^{1}$ According to Pigafetta (1525), "This beast has its head and ears of the size of a mule, and the neck and body of the fashion of a camel, the legs of a deer and the tail like that of a horse, and it neighs like a horse" (p. 50).

Pigafetta's description of a new nonhuman animal was typical of explorers from the Old World. Asúa and French (2005) call them "jigsaw-puzzle" descriptions that were "always on the verge of the monstrous and the anomalous" (p. 51). Xeres, however, observed camelid husbandry, rather than a lone camelid, and his reference to "flocks of sheep" implies a sense of familiarity with that husbandry. Horseman Miguel de Estete (1495-1572) also conveyed that sense of familiarity; he even referred to the "shepherds who keep them" ("con sus pastores que los guardan") and added that those shepherds "have their houses in the mountains, as in Spain" (Xeres, 1534, p. 77).

1 A guanaco is a wild species of camelid named today Lama guanicoe; its domesticated form is the llama (Lama glama). 
Those passing remarks on Andean camelid husbandry constitute the first eyewitness accounts, by visitors from the Old World, of widespread sophisticated ungulate husbandry in the New World. When Columbus arrived there in 1492, he had commented upon the absence of domesticated nonhuman animals (Columbus, 2010, p. 47): an absence that to Europeans suggested primitivism. Recent studies suggest that, during the 15th Century, sheep husbandry provided a crucial source of Spain's developmental capital and that "wool exports probably constituted its single most important source of foreign exchange" (Phillips, 1997, xi, pp. 287-290). To a conquistador, therefore, a flock of sheep represented a commodity, rather than a gathering of creatures with individual identities. It reflects in Xeres's use of the word "ganado" in relation to the camelids: The Spanish word "livestock" or "flock" itself derives from the verb "to gain," or "ganar" (Phillips, 1997, p. 27).

Although the conquistadors associated Andean husbandry with "civilisation," their observations of another aspect of Andean culture-the sacrifice of humans (and "sheep") in "mosques" - were interpreted as clear evidence for barbarism (Xeres, 1534, p. Xx). The conquistadors had little understanding of Andean culture, religion, or social order. Indeed, Xeres's crude terminology (viz., "mosques") characterized the earliest written accounts that emerged from the expedition (Mac Cormack, 1991, p. 51). Nevertheless, it was clear to those conquistadors that the Andean religion was certainly a false one and probably under the influence of an evil supernatural being - the Devil. Although the Spaniards noted that the Andeans sacrificed "sheep," there is no evidence that they believed that those sheep themselves had a relationship with the Devil. Rather, for a hungry army on the march and thousands of miles from reinforcements, they provided the conquistadors with a welcome source of victuals.

\section{Large Llamas with Silver Shoes}

The Andeans did not have a system of alphabet writing. However, a close reading of two narratives based on interviews with Incas, who had close connections to those involved in the first encounters with the conquistadors, offers an insight into Andeans' perceptions of horses. In the 1550s, Juan de Betanzos (c.1510-1576) compiled an account of the invasion based on interviews with Incas. $^{2}$ And Titu Cusi Yupanqui (c. 1530-1571), son of one of Atahualpa's rival half-brothers, related his account verbally in Quechua around 1570 to

2 Betanzos was interpreter and translator of Quechua for the Viceroyalty of Peru. His sources included his wife Dona Angelina Yupanque, former Inca princess. 
Fray Marcos García, an Augustine missionary. García subsequently "ordered" the account and translated it into Spanish (Yupanqui [Bauer], 1570 [2005], p. 12).

Titu Cusi explained that the Incas were uncertain of the origins of the invaders, who seemed to have emerged from the sea. They speculated whether they might be supernatural beings, "because they were very different in their dress and appearance from the people who live here and also because they rode very large animals with silver feet" ("porque diferençiauan mucho en nuestro traje y senblante, y lo otro porque beyan que andaban en vnas animalias muy grandes, las quales tenian los pies de plata"), (Yupanqui [Julien], 1570 [2006], pp. 8-9). The use of the word "animal" is significant, as pre-Columbian Quechua speakers lacked a generic term referring to any nonhuman animal (Adelaar, 2004, p. 234). ${ }^{3}$ Clearly, those Andeans who first observed horses would not have referred to them as "animals." Indeed, elsewhere Titu Cusi referred to horses as "genero de nuevas llamas" (a new kind of llama) (Yupanqui [Julien], 1570 [2006], p. 13). We remark here that when the Nahuas of Central America first encountered horses, they described them as huey maçatl (large deer): the only large ungulate they were familiar with (Lockhart, 1992, p. 270). The Nahuas, like Andeans, appear to have consciously extended words for one type of nonhuman animal to a different one.

Betanzos translated the Quechua word the Incas used for horses to the Spanish word "ovejas," though actually he meant llama (Betanzos, 1550, p. 235). His choice of ovejas reflects the contemporary lack of knowledge colonial Spaniards had of camelids, even in the 1550s. Although Cieza de León (15181555) had learned the Quechua words for the four different camelids species commonly recognized today (Cieza, 1553, p. LXXXI), the sheep label stuck and most Spaniards tended to call both llamas and alpacas "sheep of this land" to distinguish them from the sheep imported from the Old World (Hyland, 2011, p. 52). The conquistadors, though familiar with Old World sheep, did not distinguish alpacas from llamas- they were lumped together as "sheep."

Titu Cusi's reference to the horses' "silver feet" (los pies de plata) is also curious because, a few pages further, he referred to "silver shoes" ("çapatos de plata") (Yupanqui [Julien], 1570 [2006], p. 19). ${ }^{4}$ The Quechua word for feet is chaki, for shoe it is wakachu, and the word phaapatu applied to both shoe and hoof. The original Quechua word that Titu Cusi used is speculative. However, the notion of llamas wearing shoes correlates to the Incas' observation of other

3 The Quecha word for animal is animal. For horse, it is kawallu. Both are borrowed from Spanish, viz., animal and caballo.

4 Note that Bauer translates this as “... very large animals with silver feet” (Yupanqui [Bauer], 1570 , p. 60). 
unfamiliar "llama clothing": for example, the girths, saddles, and adorned metal bits around their mouths. It may additionally have provided the Andeans with an explanation for the horses' single digit (characteristic of equidae), as opposed to the two-toed camelid feet with which they were familiar.

The conquistadors were aware that their horses' aroused curiosity and encouraged it. For example, they adorned their horses with bells - a tactic borrowed from Hernán Cortés (1485-1547). An Aztec who confronted cavalry on the battlefield related the sense of shock to Bernardino de Sahagún (1499-1590), a Spanish priest:

Each had little bells they all jingled by with a shattering jangle. The horses - they looked like deer-neighed and whinnied. They were all sweating; water fell from their bodies, large flecks of foam, like soap suds flew from their mouths to the ground. Their hooves beat the dirt as they advanced, pounding, sounding like stones cast at us, piercing holes which appeared, each one separately, as each hoof lifted, as each hind leg and each foreleg stamped.

SAHUGÚN, 1555, p. 28

In contrast to the fear and awe expressed by that Aztec, when Atahualpa first encountered a horse, he showed no sign whatsoever of fear. Although Andeans did not routinely ride on llamas' backs or use them directly in combat, they were familiar with human control of large mammals. The Nahuas, on the other hand, had no previous experience, knowledge, or understanding of that.

\section{Soto's Horse}

Chroniclers recorded Atahualpa's reaction to a horse in detail, precisely because it was unexpected. It occurred when the conquistadors first reached the Inca army, camped outside the town of Cajamarca. Hernando de Soto (c. 1496/1497-1542), one of Francisco Pizarro's captains, led a small troop of horsemen to meet Atahualpa. They rode with the intent of creating a spectacle, for the Andeans reported them as riding on "sheep [camelids] and these sheep [camelids] have bells on their necks to scare those who see them" (Betanzos, 1550, p. 253). According to Xeres, Soto deliberately "forced his horse's head over the head of Atahualpa when he was sitting in state, so that the breath from the horse's nostrils moved the fringe on the Inca's forehead" (Xeres, 1534, p. 255). However, to the astonishment of the Spaniards, Atahualpa did not react; he did not even "raise his head" (Xeres, 1534, p. 255). 
For Abbass, Atahualpa's reaction (or lack of one) to Soto's horse is evidence that the Amerindians did not always "cower in terror" during initial contacts with horses (Abbass, 1986, p. 40). He additionally suggests that the Andeans' familiarity with large quadrupeds meant they would be unlikely to have perceived of horses as mysterious. Taylor (1994), however, proposes that the Amerindians of Central America regarded the Spaniards' horses as courageous, powerful animal-warriors in their own right, and though they acted in unison with their riders, they appeared to have a capacity for independent decision-making (p. 157). Certainly, the Incas would have observed a horse and rider moving in military formation, quickly accelerating, changing gait, and perhaps jumping in a controlled warlike manner but without any apparent human command.

Indeed, Xeres (1534) quotes an Inca envoy as advising Atahualpa's soldiers that horses "ran like the wind, and that those who rode them had long lances, with which they killed as many people as they met, overtaking them with two jumps while the horses killed many with their feet and mouths" (p. 42). Thus, horses were active agents of warfare. There is no evidence that Andeans trained llamas or alpacas in such a manner. ${ }^{5}$ So although their llamas provided the Andeans with knowledge that ungulates can be domesticated, the conquistadors' "llamas" were unlike any they had encountered before.

Atahualpa's display of fearlessness in the face of Soto's horse should additionally be considered within the context of his status as Emperor of the Inca Empire. At the time of the conquistadors' invasion, the Incas had developed the military and administrative capacities for governing over a population estimated at 14 million. ${ }^{6}$ The Empire had a standing army and operated sophisticated systems of agriculture and camelid husbandry. These were centrally administered by a bureaucracy that coordinated its affairs from Cuzco, via an extensive network of roads, along which runners carried messages and camelids transported goods.

That communication network provided Atahualpa with information that the conquistadors drank and ate like Andeans (and most likely that they defecated like Andeans): "They were not gods but men who died as they [Andeans] did. And the same was true of their horses" (Betanzos, 1550, p. 260). One of his envoys even advised him that, rather than supernatural beings, the invaders were in fact "robbers and wastrels who came as knights, mounted on sheep [camelids]" (P. Pizarro, 1921a, p. 172). As an Emperor confronting a rag-tag army, Atahualpa was keen to set an example to his troops. In fact, he reprimanded a company

5 For a study of llama gait, see Sluijs (2004, p. 77).

6 Cook (1981) places a lower limit for the population at approximately 3 million (p. 110). 
of his men who "stepped back a step" when Francisco Pizarro's half-brother, Hernando Pizarro (c. 1530-1560), rode his horse close to them (Mena, 1534, p. 31). ${ }^{7}$ Cieza (1999) attributed Atahualpa with the following reprimand to those soldiers: "What do you think? These are nothing but animals who are born in the land of those who bring them, just like sheep and rams [llamas and alpacas] are in yours. Why did you run away from them? You will pay with your lives for the affront I have received on your account," (p. 203). Indeed, they did pay with their lives.

Upon capturing Atahualpa in Cajamarca square, Francisco Pizarro remonstrated with him for the ruthless discipline metered out to those soldiers (Xeres, 1533, p. 66). That is curious: why would Francisco Pizarro care whether some of Atahualpa's soldiers died? Rather than a display of concern about cruelty towards one's fellow human beings, that interest in and disapproval of Atahualpa's execution of those soldiers is consistent with Francisco Pizarro's concern that the Inca troops might learn from Atahualpa, rather too quickly, that horses were not omnipotent, but were in fact mortal creatures. Francisco Pizarro wanted to impress upon Atahualpa that the soldiers' display of fear was a rational and reasonable response: that horses were not llamas but were exceptional and, for Andeans, incomprehensible and beyond their control.

\section{Cajamarca}

When Atahualpa had marched into Cajamarca square with an estimated 8,ooo troops, on November 16, 1532, the Spaniards hid their horses from the Inca behind walls where they were "decked... with bells in order to fill the Indians with fear" (P. Pizarro, 1571, p. 179). At a signal, Francisco Pizarro's men fired their cannon and muskets into the amassed Inca army before launching a cavalry, artillery, and infantry assault. Set in disarray and trapped, the Incas subsequently became easy pickings. Conquistador Estremaduan Trujillo stated that 8,00o died, most of them by trampling and "suffocation" (Stirling, 2000, pp. 36-38). The only injury incurred by the invaders was a slight wound to one of their horses.

That the conquistadors recorded that injury is indicative of the value they attached to their horses. Indeed, Xeres reported that their cavalry performed very well: "A wonderful thing was observed in this battle. It was that the horses which, the day before, could scarcely move for the cold, were able to charge with such fury that they seemed as if nothing had ever ailed them" (Xeres, 1534, p. 56). In contrast, Xeres also noted there were so many camelids

7 In addition to Cristóbel de Mena, see also Zárate (1981, p. 97) and P. Pizarro (1921a, p. 176). 
running around that orders were issued for them "to be set free, because there was a great multitude, and they encumbered the camp" (Xeres, 1534, p. 59). Horses were valued fellow combatants, while llamas were disposable.

Diamond (2005) devotes a whole chapter of Guns, Germs and Steel to the events that took place in Cajamarca square. For him it presents unequivocal evidence supporting his theory of the Old World's technical superiority. He also alludes to the Europeans' dissemination of empirical knowledge through books, which informed Francisco Pizarro of Cortes's tactics and led him to devise the strategy of capturing Atahualpa as quickly as possible. He adds that "Atahaulpa had not even heard of similar threats to anyone else, anywhere else, anywhere in history" (Diamond, 2005, p. 80). Thompson (1999) refers to it as a "trick," and points to contemporary reports that large detachments of the Inca army camped outside Cajamarca stood by while their comrades were slaughtered as evidence for "Inca political vulnerabilities" (p. 146). Raudzens (2000), though he disagrees with the significance Diamond attaches to the roles of disease and technology, regards Cajamarca more as a bloody coup d'état than a battle, which "proved nothing much about military power but plenty about the greater nastiness of the Spanish over the Incas" (p. 33). Those viewpoints, though argued from radically different interpretations of Cajamarca, imply that the Incas were naïve, not very different to how the conquistadors portrayed them.

What can we make of Atahualpa's strategy? Titu Cusi tells us that when they marched into Cajamarca square, the Inca troops "brought no weapons for battle or harnesses for defene. only tomës (which is how we call our knives) and lassos for the purpose of hu $\&$, this new kind of llamas" (Yupanqui 1570, p. 61). Pedro Pizarro (1921a) added that the Incas had "prepared many ropes in order to tie them [the horses]" (p. 173). According to Hernando Pizarro (1533), Atahualpa had been advised by his envoys that the conquistadors were "not warriors, that the horses were unsaddled at night, and that with two hundred Indians he could defeat them all" (p. 119). Thus, when he marched into Cajamarca, Atahualpa had been briefed on the invaders' swords, horses and cannon, but considered his own troops equal to the conquistadors, man for man.

Indeed, Cieza (1999) tells us that Atahualpa entered Cajamarca under pretence of peace, but had declared to his men his intention to seize all the invaders and make a "solemn sacrifice of the horses - in which their [the Spaniards'] strength lay_and to take them as slaves" (p. 205). Establishing close quarters with the conquistadors under the pretence of peace, of outnumbering and disarming them, was a logical way of neutralizing their observed advantages. Rather than a naive victim of cunning Spanish plotting (as both Raudzens and Diamond imply), Estete's, Yupanqui's, and Cieza's accounts suggest that Atahualpa, an experienced and ruthless military commander himself, had devised a plot that mirrored that of the Spaniards. According to Cieza (1999), 
the conquistadors learned of Atahualpa's plan. He added that if they had not "it would be impossible for our men ... to defend themselves from the many against them" (p. 207).

Under interrogation, Atahualpa disclosed to his Spanish captors that he intended to "take our horses and mares, which was what impressed him most, for breeding, and to castrate some of us for his service to guard his women, as was their custom, the rest he would sacrifice to the sun" (Estete, 1534, p. 378). Evidently, horses rather than the conquistadors' other weaponry-that is, their cannon, swords or armour - were central to Atahualpa's strategy. Even when his envoys reported on the conquistadors' swords, the chroniclers recorded Atahualpa as expressing particular interest in how the conquistadors used them to slaughter llamas (Betanzos, 1571, p. 237). ${ }^{8}$ Atahualpa's intention of sacrificing, in addition to capturing and breeding the Spaniards' "large llamas," sheds light on another aspect of his particular interest in the horses; horses, as a type of camelid, had spiritual significance.

Camelid husbandry integrated into Andean everyday life and played a prominent role in religious practices such as sacrificial ceremonies. Urton (1981) provides a comprehensive explanation of how the Incas allocated different colored llamas for sacrifice according to the observed motion of two bright stars named $\alpha$ and $\beta$ Centaurii and the Milky Way, which the Incas recognized as the "eyes of the llama" and the "Dark Cloud," respectively. The Incas made connections between the motion of those constellations and the llama breeding cycle; the llama gestation period starts in December and lasts for eleven months. That unity between the observed motion of the stars and everyday life extended to other nonhuman animals. Polo de Ondegardo (d. 1575) wrote that, "in general the Incas believed that all the animals and birds of the earth had their likeness in the sky in whose responsibility was their procreation and augmentation" (Urton, 1981, p. 110). Thus, the Incas comprehended the conquistadors' horses within a cosmological framework, about which the whole of their culture revolved.

\section{Pachacamá}

With the conquistadors blockaded in Cajamarca and holding Atahualpa prisoner, Francisco Pizarro secured a short-lived period of "peace." On January 5,

8 Missionary Bernabé Cobo (1582-1657) described sacrificial ceremonies in which an Inca "priest" led a llama several times around an idol, took the creature over his right arm, turned the llama's eyes towards the "god" to whom the sacrifice was directed, spoke certain words appropriate for the occasion, and slit the llama's throat (Cobo, 1653, p. 114). 
1533, he sent Hernando Pizarro, with a couple of Spaniards (one of whom was Miguel Estete) on an excursion to collect gold for Atahualpa's ransom. They were accompanied by some Andean allies, led by Chilicuchima, an Inca captain.

On February 5, the troop arrived in Pachacamá, where they learned that an elderly Andean page had advised an Inca chief not to fear the Spaniards' horses because "they could do no harm" (H. Pizarro, 1533, p. 124). Hernando Pizarro (1533) noted that Inca page "was one of the chief and most confidential servants of their god" (p. 124). For a monotheist, that god must have been a false one and therefore could be a manifestation of the Devil, or the Devil himself. However, Hernando Pizarro did not believe that the page was really communicating with the Devil but conjectured that he pretended to. Hernando Pizarro demanded that the page admit to that. He subsequently tortured the old man but found him to be "so stubborn in his evil creed, that I could never gather anything from him, but that they really held their Devil to be a god" (H. Pizarro, 1533, p. 124).

MacCormack (1991) points out that other conquistadors, when confronted with Inca idols that the Amerindian priests claimed could speak, believed that the Devil actually did speak through those idols and interprets Hernando Pizarro's standpoint as the brash logic of a soldier (p. 627). ${ }^{9}$ Lamara (2008) queries the "fixation on horses," and suggests that the answer "lies in silenced acts involving magicality, performed by both Spaniards and Incas" (p. 71$).{ }^{10} \mathrm{We}$ propose that Hernando Pizarro's standpoint reflected concern for the implications for him and his men if that page really was communicating with the Devil. The Devil understood the Christian god's logic: He knew all about deception, such as the Spaniards' trickery in encouraging Andeans to believe horses were supernatural beings. The Devil was not only clever, but he was also intrinsically rebellious. Advice from the Devil could serve to embolden the Andeans to defy the Spaniards' authority.

There is further evidence of Hernando Pizarro's particular keenness to encourage Andeans to believe in the omnipotence of horses. Some months

9 Cristóbel de Mena wrote that in that temple "a Devil used to talk to the Indians in a very dark room which was as dirty as the devil himself" (Mena, 1534, p. 37).

10 Lamara (2008) speculates that Atahualpa deliberately encouraged his subjects to perceive horses as strange, eerie creatures who eat gold and silver, because he did not want his subjects to conclude that mere mortals had captured him, which might undermine his personal aura and status. However, that is inconsistent with Atahualpa's public execution of some of his soldiers for their display of fear of horses and his speech admonishing those unfortunate men, in which he proclaimed that horses were like llamas (Lamara, 2008). 
earlier, following a battle at the port at Tumbez, he had ordered his men to bury a horse that the Amerindians had killed "so that the Indians of Tumbez would not believe that they had the power to kill a horse" (Cieza, 1999, p. 167). And it was Hernando Pizarro who deliberately rode his horse into the troop of soldiers (whom Atahualpa subsequently executed) when Soto visited the Inca encampment outside Cajamarca. Furthermore, Estete (1534) tells us that after leaving Pachacamá, he and Hernando Pizarro went in pursuit of Chilicuchima (who had rallied a force of Incas against the Spaniards). In early March, when they arrived in the town of Xauxa, Hernando Pizarro ordered the Andeans to clear the town square because the "Horses were angry and would kill them" (Estete, 1534, p. 88). Thus, Hernando Pizarro sought to reinforce the supernatural status of horses. In doing so, he intensified the power of horses in the physical world and therefore the dominance of the conquistadors over the Andeans.

\section{Horses in the Combat Zone, Post-Cajamarca}

In the aftermath of Cajamarca, those Andeans who resisted the Spaniards developed tactics to oppose horses. Don Alonzo Enríquez Guzmán (1518-1543), an equestrian himself, referred to some of those tactics. They included the use of ayllas, which Guzmán described as "consisting of three round stones sewn up in leather, and each fastened to a cord a cubit long" (Markham, 1862, p. 101). The Andeans threw their ayllas at the horses, and "thus bind their legs together; and sometimes they will fasten a man's arms to his sides in the same way" (Markham, 1862, p. 101). They also used slings, with which they could "hurl a huge stone with such force that it will kill a horse," and which Guzmán considered to have an effectiveness a "little less great than that of an harquebus" (Markham, 1862, p. 101).

Markham (1862) added that the Andeans dug "endless number of deep holes, with stakes bristling in them, and covered over with straw and earth. The horses often fell into them; and the rider was generally killed" (p. 101). ${ }^{11}$ Guzmán also remarked that the Andeans were "much afraid of our horses" but that "their mountains offer an excellent means of defence against them" (Markham, 1862, p. 101). It is noteworthy that in his discussion of the Andeans' tactics, Guzmán only referred to those used to counter horses.

Titu Cusi relates that during a siege of Cuzco, in 1536, the Andeans were thwarted in their assault on the Spaniards because a "white horse ... did them [the Andeans] a lot of damage" (un cuallo blanco... les hazia mucho daño)

11 Cieza de León (1999) also describes the Andeans' counter-cavalry tactics (pp. 278-281). 
(Yupanqui [Julien], 1570[2006], pp. 102-103). Titu Cusi's use of the Quechua word for horse, cauallo (which derives from the Spanish word caballo) suggests that, by 1536, the Andeans recognized horses as distinct nonhuman animals, rather than large llamas. That Titu Cusi remembered the horse was white is indicative of the sense that individual horses were active participants in a battle. It also highlights the importance Andeans attached to color.

Inca Garcilaso de la Vega (1539-1616) explained that the Incas separated and selected camelids according to color (Vega, 1609, p. 220). Crisóbel de Molina (1529-1585), a priest attached to a hospital for Andeans, established in Cuzco, wrote in 1571 that the Incas called llamas that were "white and woolly" huacarpaña, while white and woolly alpacas were called cuyllos [bright whites]. Likewise, reddish alpacas were called paucarpacos, grey ones oquipacos, large chestnut brown llamas were called chumpi, and black llamas were called llanca llama (Molina, c. 1574, p. 21).

Echoes of that use of "color coding" can be detected today. Research on present-day herding in Isluga showed that while herders may count their (Old World) sheep, who are not easily distinguished from each other, they never count their llamas or alpacas but check that all are present by observation of characteristic patterns of marking (Dransart, 2002, p. 78). The Andeans' identification of individual camelids according to color patterns has no correspondence with Old World sheep or cattle husbandry. Rather, it correlates more closely with the relationship established between Old World humans and dogs, cats, and horses.

According to Cieza de León (1999), Andean fighters cut the feet off any horses they managed to kill on the battlefield (p. 461). Ogburn (2007) tells us that trophy taking of human body parts, generally involving the severed heads of chiefs or other leaders captured in battle, was widespread in pre-Hispanic Andes. The main purpose of the trophy taking was to establish or reinforce status and power (Ogburn, 2007, p. 505). Ogburn does not mention feet or horses. However, if those Andeans who cut off horses' feet were similarly motivated, then it implies that they perceived those horses as powerful warriors. For their part, Spaniards fought hard to avoid losing their horses. Horse guardianship required a major financial investment and conferred high social status. Cieza de León (1999) related how Francisco Pizarro fell from his horse and an Andean "with great boldness" led it away, only to be pursued by Francisco Pizarro who "stabbed him to death and collected his horse" (p. 461).

By 1538 , there is clear evidence that Andeans began to use weapons captured from the Spaniards. Pedro Pizarro (1921b) described the trouble the Spaniards had in overcoming an Inca warrior equipped with "a shield upon his arms and a sword in his hand and a cudgel in the shield-hand and a morion [type of 
helmet used by Spaniards] upon his head" (p. 315). He related that Hernando Pizarro admired that Andean's fighting skills and ordered his men to take him alive. However, rather than be captured, the Andean jumped off a battlement to his death. In adopting Spanish weapons and fighting in a manner that the conquistadors considered chivalrous, that Andean earned a degree of respect.

Manco Inca Yupanqui (1516-1544) rode a horse. He was equipped with a saddle and bridle and according to his son, was a skilled rider (Yupanqui [Julien], 1570 [2006], p. 125), though he appears to have been the only equestrian in his insurrectionary army. Thus, when Inca Manco acquired that Old World, nonhuman animal, he additionally acquired Old World concepts of personal guardianship and social status; they came as a package. He mimicked the hidalgo.

\section{Conclusion}

In trying to make sense of each other's ungulates, both Andeans and Spaniards detected signs of familiarity, but also of otherness. The Spaniards encountered alpacas and llamas within the context of Andean camelid husbandry, for which they drew parallels with Old World husbandry. Camelids were sheepharmless but useful sources of protein. The Andeans, however, encountered just 62 horses within a military, rather than pastoral, context. Consequently, although their experience of camelid husbandry equipped them with a benchmark for understanding how large ungulates could be integrated into their everyday lives, they were entirely unfamiliar with their military role. Indeed, if early on in the invasion they had acquired knowledge of horse husbandrythat is, stables, horses running around in enclosures, grooming, breeding, and so forth-then the impact of those 62 horses may well have diminished.

As it is, historians have long highlighted the key role of horses in the invasion of the Inca Empire (Graham, 2004). Abbass (1986), however, has raised some important objections to the assumption that Amerindians cowered when confronted by horses. This paper agrees with some of those objections, in particular Abbass's allusion to Atahualpa's encounter with Soto's horse shows that assumption to be plain wrong. While this paper draws different conclusions to Abbass on that incident and retains the decisive role of horses in the invasion, it hopes to encourage analysis that considers that role within a wider context of human-nonhuman animal relations.

Diamond (2005) sets out a general theory that attributes the collapse of civilizations in the New World to their relative military puniness when confronted by Old World technology. He places nonhuman animals at the core of the development of that technology. He identifies fourteen ancient species 
of large, domesticated mammal, five of which he classifies as "major" above nine "minor" species. The major ones are the horse, cow, sheep, pig and goat. Included in the "minor" list are donkeys, reindeer, water buffalo, yak, bali cattle, mithan, and the four species of camelids-Arabian camel, Bactrian camel, llama, and alpaca. ${ }^{12}$

The latter two species are the only representatives from Diamond's list who emerged outside of Eurasia. The distinction between the major and minor classes is that the latter was geographically restricted and consequently affected people in limited areas of the planet. Given the extent of camelid husbandry in the Andes, one wonders why Diamond classifies Andean camelids as "minor." Furthermore, Andean camelid husbandry revolved around wool, meat, and dung: these are similar roles to sheep and cattle, who belong to Diamond's list of major species. Indeed, Diamond (2005) himself remarks that it is "tempting to consider camelids as the Andean equivalent of Eurasian livestock," though he does not elucidate (p. 213).

One wonders how his theory would stand, if he included alpacas and llamas in the major list, for that list establishes the platform for his theory of Old World superiority. That theory, though perhaps useful as a sort of guide, does not account for differences in the ways that each of those nonhuman animals integrated within the everyday lives of humans. In the case of Andeans and Old World Europeans, there were fundamental differences, which became apparent when the conquistadors invaded the Inca Empire. They affected the course of the conflict and call into question the meanings and definitions of "domesticated animal."

The Incas organized alpaca and llama herds according to three designations: one for the state, one for religion, and the other for the use of those who maintained the herds. It was a sort of state collectivism, which reinforced the hegemony of the Inca elite and their religion. For each new territory they conquered, the Incas imposed that system (Polo, 1571, p. 155). While the Inca system of camelid husbandry implied a sense of guardianship over camelids, it did not involve private/personal guardianship. Old World husbandry, on the other hand, operated according to a system based on private property. It distinguished between "domesticated" and "wild" nonhuman animals. Humans owned and controlled the former but not the latter. Andeans did not make that distinction in the ways that Europeans did. Furthermore, the Inca system of husbandry — of allocating camelids according to state, religion, and the community — extended to vicuñas and guanacos: "wild" camelids (Dransart, 2002, p. 30).

12 Fossil evidence suggests that camelids originated in North America and made their way across the Baltic Straits to Asia (the camel and dromedary), and southwards to Peru and beyond (Wheeler, Russell, \& Redden, 1995).

SOCIETY \& ANIMALS 25 (2017) 145-162 
More fundamentally, Andeans and conquistadors held different views on the status of humans with respect to the nonhuman animals with whom they coexisted. The monotheist conquistadors assumed that their god created humans specially. All other nonhuman animals (also created by that god) were subsidiary, though the domesticated ones served as useful resources, gifts from their god. Indeed, in his ponderings over the origin of the New World animals, Cieza concluded that must apply to llamas too- they were also gifts from the Christian god - and Cieza embraced them as among the "most excellent animals that God created" (Cieza, 1999, p. CXI).

While Cieza's musings are better analyzed in their colonial context (by 1553 Spaniards valued llamas for various reasons, e.g., for mining activities), they reflect a fundamental difference between Old World and Andean viewpoints of nonhuman animals. As mentioned earlier, Andeans did not have a special word for generic nonhuman animals. Rather, humans and nonhuman animals coexisted; they were sentient fellow travellers through life: And through death.

Indeed, Andean concepts of "human" and "nonhuman animal" had a degree of flexibility. ${ }^{13}$ For example, an Andean could present himself/herself for sacrifice to an Inca priest in order to do service in the "other land." It was also possible for a llama to substitute for a human in that role. Father Blas Valera (1545-1597) explained that "not only did they call the livestock who was to die for men runa, men, huarmi, women, huahua, children, but they also gave to the animals proper names of those who had offered their lives" (Hyland, 2011, p. 6o). Valera added that the Andeans used the word huahua for baby llamas as well as for children. Similarly, the word yuyac could mean animals who substituted for adults in sacrificial ceremonies (Hyland, 2011, p. 56).

MacCormack (1991) interprets Andean camelid-human relationships as one of interchangeability in which "llamas were represented as interacting with humans on an equal level" (MacCormack, 1991, p. 171). We note here that the Quechua word for a "domesticated" nonhuman animal is uywa. However, in Quechua uywa are both uywasqa "cared for" and uywaq "carers" (Mannheim, 1991, p. 89). Thus, the meaning of domestication of nonhuman animals is different from the Old World meaning and perhaps uywa translates better as "companion nonhuman animal."

Alves (2011) describes how humans in non-agricultural and pre-industrial societies perceive animals and nature as sentient (Alves, 2011, p. 25). Evidently, although they engaged in agriculture and pastoralism, the Incas had not abandoned that perception. It is also detectable in the conquistadors' relationship with their

13 Léon Garagarza (2013) describes similar beliefs amongst Amerindians who resisted colonial rule in Mesoamerica, in 1558: “... human-animal metamorphosis could occur at any time" (p. 51). 
horses. Thompson (2011) states: "No human-animal relationship is more intimate, both mentally and physically, than that between mount and rider, for the two share an interspecies unity of understanding and kinetic communication that is unparalleled" (p. 231). That relationship intensified in a military conflict, more so for the small army of conquistadors, thousands of miles from home. Those conquistadors relied on their horses for safe passage through their invasion.

The aura of mysticism they fostered around horses bolstered their superiority and power. However, it also reinforced and illuminated the strong bond of intimacy that lay at the heart of their relationships with their horsesrelationships forged through personal guardianship but which mirrored the Quechua definition of uywa. Thus, during the invasion, the categories of "human" and "animal" as understood by the protagonists were perturbed. Further research is required to investigate both the blurring and the perseverance of those categories during the early and later colonial periods.

\section{References}

Abbass, D. K. (1986). Horses and heroes: The myth of the importance of the horse to the conquest of the indies. Terrae Inconitae, 18, 21-41.

Adelaar, W. F. H. (2004). The languages of the Andes. Cambridge: Cambridge University Press.

Alves, A. (2011). The animals of Spain: An introduction to imperial perceptions and human interaction with other animals, 1492-1826. Boston: Brill.

Asúa, M., \& French, R. (2005). A history of new world animals. Aldershot: Ashgate Publishing Limited.

Betanzos, J. (1996). Narrative of the Incas. (R. Hamilton \& D. Buchanan, Trans.). Austin: University of Texas Press. (Original work published c. 1550).

Cieza de León, P. (1553). Parte primera de la chrónica del Perú. Seville.

Cieza de León, P. (1999). The discovery and conquest of Peru. (A. Cook \& D. Noble, Trans.). Durham and London: Duke University Press Books. (Original work unpublished).

Cobo, B. (1990). History of the Inca empire: An account of the Indians' customs. Austin: University of Texas Press. (Original work published 1653).

Columbus, C. (1893). Journal of Christopher Columbus. (C. Markham, Trans.). London: Hakluyt Society. (Original work published c. 1493).

Cook, N. (1981). Demographic collapse: Indian Peru, 1520-1620. Cambridge: Cambridge University Press.

De Ayala, G. P. (2006). The first new chronicle and good government. (D. Frye, Trans. and Ed). Indianapolis: Hackett Publishing Company. (Original Work written c. 1615 and published 1930). 
De la Vega, G. (1888). Royal commentaries of the Incas and general history of Peru. The first part. (C. Markham, Trans.). London: Hakluyt Society. (Original works published 1609).

De Mena, C. (1929). A Report of the conquest of Peru as recorded by a member of the Pizarro expedition. (J. Sinclair, Trans.). New York. (Original Work published c. 1534).

De Molina, C. (2011). Account of the fables and rites of the Incas. (B. Bauer, Trans.). Austin: University of Texas Press. (Original Work published c. 1574).

De Ondegardo, P. (1571). Los errores y superstiones de los Indies. (Lima).

De Sahugún, B. (1978). The war of conquest: How it was waged here in Mexico. A. Anderson \& C. Dibble (Eds.). Utah: University of Utah. (Original work published 1555).

De Zárate, A. (1981). The discovery and conquest of Peru. (J. Cohen, Trans.). London: Penguin. (Original work published 1555).

Diamond, J. (2005). Guns, germs and steel. London: Vintage Books.

Dransart, P. (2002). Earth, water, fleece and fabric: An ethnography and archaeology of Andean camelid herding. London: Routledge.

Estete, M. (1534). Report of Miguel Estete on the expedition. In Reports on the discovery of Peru (C. Markham, Trans.). New York.

Garagarza, L. (2013). Animals, culture and colonialism. In M. Few \& Z. Tortorici (Eds.), Centering animals in Latin American history (pp. 31-61). Durham and London: Duke University Press.

Goňalons, G. (2008). Camelids in ancient Andean societies: A review of the zooarchaeological evidence. Quaternary International, 185, 59-68.

Graham, C. R. B. (2004). Horses of the conquest: A study of the Spanish conquistadors. Long Riders' Guild Press. (Original work published 1930).

Hyland, S. (2011). Gods of the Andes: An early Jesuit account of Inca religion and Andean Christianity. Pennsylvania: Pennsylvania State University Press.

Lamara, G. (2008). Domination without dominance: Inca-Spanish encounters in early colonial Peru. Durham: Duke University Press.

Lockhart, J. (1992). The Nahuas after the conquest: A social and cultural history of the Indians of Central America. Stanford: Stanford University Press.

MacCormack, S. (1991). Vision and imagination in early colonial Peru. Princeton: Princeton University Press.

MacCormack, S. (2006). Gods, demons and idols of the Andes. Journal of the History of Ideas, 67(4), 623-647.

Mannheim, B. (1991). The language of the Inka since the European invasion. Texas: University of Texas Press.

Markham, C. (1862). The life and acts of Don Alonzo Enríquez Guzmán. London: Hakluyt Society. 
Ogburn, D. (2007). Human trophies in the late pre-Hispanic Andes. In R. Chacon \& D. Dye (Eds.), HYPERLINK "http://link.springer.com/book/10.1007/978-0-38748303-0" The taking and displaying of human body parts as trophies by Amerindians: Interdisciplinary contributions to archaeology (pp. 505-522). New York: Springer Science \& Business Media.

Phillips, C. R., \& Phillips, W. D. (1997). Spain's golden fleece: Wool production and the wool trade from the middle ages to the nineteenth century. Baltimore: The Johns Hopkins University Press.

Pigafetta, A. (1874). The first voyage round the world by Magellan. Cambridge: Cambridge University Press. (Original work published 1525).

Pizarro, H. (1872). Letter from Hernando Pizarro to the Royal Audience of Santo Domingo. In Reports on the discovery of Peru (C. Markham, Trans.). London: Hakluyt Society. (Original work published 1533).

Pizarro, P. (1921a). Relation of the discovery and conquestaz of the kingdoms of Peru. Vol I. (P. Means, Trans.). New York. (Original work published 1571).

Pizarro, P. (1921b). Relation of the discovery and conquest of the kingdoms of Peru. Vol II. (P. Means, Trans.). New York. (Original work published 1571).

Raudzens, G. (2001). Outfighting or outpopulating? Main reasons for early colonial conquests 1513-1813. In G. Raudzens (Ed.). Technology, disease and colonial conquests: Sixteenth to eighteenth centuries (pp. 127-167). Leiden: Brill.

Sluijs, L. (2004). Locomotion and energetics of llamas and alpacas under free-ranging conditions. Gottinge: Cuvillier.

Stirling, S. (2000). The last conquistador. Frome: Sutton Pub Ltd.

Thompson, K. (2011). Theorising rider-horse relations: An ethnographic illustration of the centaur metaphor in the Spanish bull fight. In N. Taylor \& T. Signal (Eds.), Theorising animals (pp. 221-253). Boston: Brill.

Thompson, W. (1999). The military superiority thesis and the ascendancy of Western Eurasia in the world system. Journal of World History, 10(1), 143-178.

Urton, G. (1981). Animals and astronomy in the Quechua universe. Proceedings of the American Philosophical Society, 125(2), 110-127.

Wheeler, J., Russel, A. J. F., \& Redden, H. (1995). Llamas and alpacas: Pre-conquest breeds and post-conquest hybrids. Journal of Archaeological Science, 22, 833-840.

Xeres, F. (1872). The narrative. In C. Markham (Ed.), Reports on the discovery of Peru. New York: Hakluyt Society. (Original work published 1534).

Yupanqui, T. C. (2005). The Inca account of the conquest of Peru (R. Bauer, Trans.). Boulder: University Press of Colorado. (Original work published 1570).

Yupanqui, T. C. (2006). How the Spanish arrived in Peru (C. Julien, Trans.). Indianapolis: Hackett Publishing Co. (Original work published 1570). 